Joaquín Arroyo-Cabrales*, Alfred L. Gardner, Bernard Sigé, Francois Catzeflis

and Timothy J. McCarthy ${ }^{\mathrm{a}}$

\title{
Taxonomic reassessment of bats from Castelnau's expedition to South America (1843-1847): Phyllostoma angusticeps Gervais, 1856 (Chiroptera, Phyllostomidae)
}

DOI 10.1515/mammalia-2016-0043

Received April 4, 2016; accepted July 20, 2016

\begin{abstract}
Gervais, in 1856, described the bats collected during Castelnau's expedition through South America (1843-1847). We report that Phyllostoma angusticeps (Gervais, 1856), long treated as a junior synonym of Phyllostomus discolor (Wagner, 1843), is not a representative of the genus Phyllostomus. In fact, as we demonstrate, it represents the taxon known as Trachops cirrhosus. We also provide a summary, in tabular form, of the genera and species first described by Gervais (1856).
\end{abstract}

Keywords: Castelnau; Chiroptera taxonomy; Phyllostoma angusticeps; Phyllostomus discolor; Trachops cirrhosus.

\section{Introduction}

Francis Louis Nompar de Caumont La Force, comte de Castelnau, who also liked to be called Francis de Laporte de Castelnau (1810-1880) was a French entomologist who,

a Deceased.

*Corresponding author: Joaquín Arroyo-Cabrales, Laboratorio de Arqueozoología “M. en C. Ticul Álvarez Solórzano”, Subdirección de Laboratorios y Apoyo Académico, Instituto Nacional de Antropología e Historia, Moneda \# 16, Col. Centro, 06060 México, D. F., Mexico, e-mail: arromatu@hotmail.com

Alfred L. Gardner: USGS Patuxent Wildlife Research Center, MRC 111, National Museum of Natural History, Washington, DC 20560-0111, USA

Bernard Sigé: Centre de Paléontologie, FRE-CNRS 2158, Université Claude Bernard-Lyon 1, 27-43 boulevard du 11 Novembre, F-69622 Villeurbanne cedex, France

Francois Catzeflis: Institut des Sciences de l'Evolution, CNRS UMR5554, Université de Montpellier, F-34095 Montpellier, France

Timothy J. McCarthy: Section of Mammals, Carnegie Museum of Natural History, Pittsburgh, PA, USA due to his political skills, was invited to serve as the American Consul in Lima, Peru. Before he assumed that post, the French government sent him on an expedition through South America that ended up taking 5 years, between 1843 and 1847. Castelnau and his party arrived in Rio de Janeiro aboard the French brig Dupetit-Thouars, where he began his magnetic, botanical, zoological, and meteorological observations. The expedition traveled across Brazil from Rio de Janeiro via the states of Minas Gerais, Goiás, and Mato Grosso. They explored northern Mato Grosso and then followed a southward route along the Paraguay River as far as Fuerte Olimpo, Paraguay. Returning to the state of Mato Grosso, they entered Bolivia and traveled to Chuquisaca [=Sucre], which at the time was the country's capital. From Chuquisaca, their journey took them to Potosí, then northward through Oruro and La Paz on their way to Puno, Peru, and then west to the Peruvian coast. From there they journeyed to Lima, where they spent some time before ascending the Andes to Cuzco, and then began a torturous decent on and along the Urubamba River to the Ucayali and eventually down the Amazon to Pará [=Belém]. From the mouth of the Amazon, they sailed north to the Guianas. Castelnau returned to Europe from Georgetown, British Guiana [=Guyana], but took the opportunity to visit islands in the Antilles on his way back. A large portion of the manuscript records was lost in Peru when a member of the expedition, Eugène d'Osery, was killed by Indians during the descent along the Urubamba River. However, journals were saved and, along with other records previously sent to Paris, became the sources to document the expedition (Castelnau 1850-1856; also see Papavero [1971, 1:149-159, map]).

The French zoologist Paul Gervais (Gervais 1856) described Castelnau's specimens of bats. Gervais (1856:27) used three different collections as the basis of his research. The main series consisted of bats collected by Castelnau and Deville in several localities from the Amazon basin during their extensive travels in that region (1843-1847). 
We are not aware of what became of this collection; it may have been subdivided among several European museum and private collections. The second collection consisted of bats obtained by Castelnau during his 1848 stay in Bahia, Brazil, where he served as French consul. Castelnau offered this collection to the Muséum Nacional d'Histoire Naturelle (MNHN), Paris, where it probably remains, at least in part. The third collection was provided to Gervais by M. Alexandre Westphal-Castelnau (1801-1867) and consisted of specimens collected by Francis de Castelnau in the state of Bahia and deposited in the collection of the Faculty of Sciences in Montpellier. This last series is known as the "Westphal collection."

Carter and Dolan (1978:134-135) listed seven taxa, which Gervais had described from the Castelnau collections, and assumed that the types would have been at the MNHN's Mammal Collection, but they did not find any of Gervais' holotypes there. Notice however that Rode (1941) had listed two of Gervais' types from the MNHN not related to Castelnau collections: Nyctiellus lepidus (Gervais 1837; see Table 1) and Proboscidea villosa Gervais, 1856 and Vespertilio dutertreus Gervais, 1837. Carter and Dolan (1978) overlooked Vespertilio dutertreus and did not locate the type of Nyctiellus lepidus. Apparently, many of the specimens Gervais (1856) described (Tables 1 and 2) either were sold or otherwise distributed to other natural history museums, including the British Museum in London. Nothing was found in the Naturhistorisches Museum, Vienna, Austria or in the Zoologisches Museum der Humboldt Universität, Berlin, Germany. N. lepidus would have been part of the material deposited at the Académie des Sciences de Montpellier as part of the M. Westphal-Castelnau collection.
In the 1990s, the zoological collections of the Montpellier University were dispersed and the vertebrates sent to the Paleontology collection. Among skins and skulls of bats, there is a specimen (CHI-073-001) labeled as Phyllostoma angusticeps from the Westphal collection currently identified as the holotype for that species. Historically, perhaps beginning with Dobson (1878:487), the name P. angusticeps has been treated as a synonym of Phyllostomus discolor (Wagner, 1843).

In 2006, J. Arroyo-Cabrales and T. J. McCarthy had the opportunity to examine this holotype and determined that it was not a species of the genus Phyllostomus. Here we formally reassess the identity of Phyllostoma angusticeps as an initial report on the available Castelnau bat collections.

\section{Materials and methods}

The Westphal-Castelnau Collection in the Department of Paleontology of the Université de Montpellier was studied. Bat specimens were reassessed by means of the most recent taxonomic keys by Williams and Genoways (2008). Dimensions of the holotype of Phyllostoma angusticeps were measured using a digital caliper Fowler Ultra-Cal III. Digital photographs were taken with a 7.2 Cybershot Sony camera. To provide a basis for comparisons, five other phyllostomids of comparable size from eastern Brazil were also measured (Table 3): Lophostoma silvicolum d'Orbigny, 1836; Phyllostomus discolor (Wagner, 1843); P. elongatus (Geoffroy St.-Hilaire, 1810); Tonatia saurophila Koopman and Williams, 1951; and Trachops cirrhosus (Spix, 1823). The measurements for these species are from specimens deposited in the National Museum of Natural History

Table 1: List of new genera described by Gervais (1856) resulting from identifying the Chiroptera in the Castelnau collections; including page number, type species, and current status of generic name according to the recent literature (modified from Simmons, 2005).

\begin{tabular}{|c|c|c|}
\hline Name, page number & Type species & Current generic name \\
\hline Pteroderma, p. 34 & 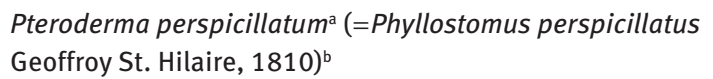 & Artibeus Leach, 1821 \\
\hline Dermanura, p. 36 & Dermanura cinereum Gervais, $1856^{\mathrm{a}}$ & Dermanura Gervais, 1856 \\
\hline Hemiderma, p. 43 & $\begin{array}{l}\text { Hemiderma brevicaudum }{ }^{\text {a }} \text { (=Phyllostoma brevicaudum } \\
\text { Schinz, 1821) }\end{array}$ & Carollia Gray, 1838 \\
\hline Tylostoma, p. 49 & Tylostoma bidens ${ }^{\complement}$ (=Vampyrus bidens Spix, 1823) & Tonatia Gray, 1827 \\
\hline Schizostoma, p. 49 & Schizostoma minutum Gervais, $1856^{\mathrm{a}}$ & Micronycteris Gray, 1866 \\
\hline Spectrellum, p. 51 & Spectrellum macrourum Gervais, $1856^{\mathrm{a}}$ & Natalus Gray, 1838 \\
\hline Promops, p. 58 & $\begin{array}{l}\text { Promops ursinus Gervais, } 1856^{\text {a }} \text { (=Molossus nasutus } \\
\text { Spix, 1823) }\end{array}$ & Promops Gervais, 1856 \\
\hline Histiotus, p. 77 & Histiotus velatus Gervais, $1856^{a}$ & Histiotus Gervais, 1856 \\
\hline Nyctiellus, p. 84 & Nyctiellus lepidus a (=Vespertilio lepidus Gervais, 1837) & Nyctiellus Gervais, 1856 \\
\hline
\end{tabular}

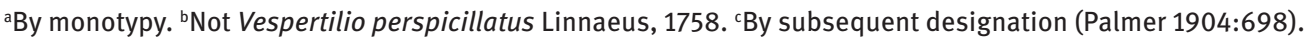


Table 2: List of new species described by Gervais (1856) from the Castelnau collections, the page number where described, and current identification in the recent literature (modified after Simmons, 2005). The types were not located by Carter and Dolan (1978).

\begin{tabular}{ll}
\hline $\begin{array}{l}\text { Dermanura cinereum, } \\
\text { p. } 36\end{array}$ & $\begin{array}{l}\text { Dermanura cinerea } \\
\text { (Gervais, 1856) }\end{array}$ \\
Phyllostoma & Phyllostomus discolor \\
angusticeps, p. $47^{\text {a }}$ & (Wagner, 1843) \\
Schizostoma minutum, & $\begin{array}{l}\text { Micronycteris minuta } \\
\text { p. } 50^{\text {a }}\end{array}$ \\
Spectrellum macrourum, & Natalus macrourus \\
p. 51 & (Gervais, 1856) \\
Emballonura brunnea, & Peropteryx macrotis \\
p. 66 & (Wagner, 1843) \\
Proboscidea villosa, & Rhynchonycteris naso \\
p. 68 & (Wied, 1820) \\
Nycticejus ega, p. 73 & Lasiurus ega (Gervais, \\
& 1856) \\
Vespertilio (Myotis) & Myotis ruber (Geoffroy \\
kinnamon, p. 84 & St.-Hilaire, 1806) \\
\hline
\end{tabular}

aRepresented in the M. Westphal-Castelnau Collection. ${ }^{\mathrm{b}}$ See Garbino and Tejedor 2012.

'Species overlooked by Carter and Dolan 1978.

(USNM), Smithsonian Institution. Additional measurements taken into consideration are those reported by Cramer et al. (2001) - T. cirrhosus; Kwiecinski (2006) - P. discolor; and Medellín and Arita (1989) - L. silvicolum.

\section{Results and discussion}

\section{Phyllostoma angusticeps Gervais, 1856 (CHI-073-001 ㅇ)}

The specimen is preserved as a study skin with wings extended; ears are flat with rounded tips (Figures 1 and 2).
The skull has been removed, but is not associated with the skin, and is considered lost.

Few measurements could be secured from the specimen (Table 3), and the lengths of forearm and tibia are likely the most accurate. The tail appears to be short (2-3 vertebrae); the near full wingspan measures about $40 \mathrm{~cm}$. The ears have rounded tips, similar to those of Tonatia saurophila and Trachops cirrhosus; whereas, the ear of Phyllostomus discolor and P. elongatus are more pointed. The ear tips of Lophostoma silvicolum are rounded, but somewhat more narrowly than in Phyllostoma angusticeps.

As pointed out, we have compared the measurements of the holotype of Phyllostoma angusticeps with those of other phyllostomine bats of approximately the same size. Although $P$. angusticeps has been treated as a junior synonym of Phyllostomus discolor, as can be seen in Table 3 , the tibia is considerably shorter in $P$. discolor. The total length of $P$. angusticeps falls within the ranges of the five species we measured for comparative purposes (Table 3). In the absence of fresh measurements of the ears of $P$. angusticeps and because dry ears do not offer trustworthy measurements, ear length is not considered. Nevertheless, ear measurements of $P$. discolor are clearly the shortest and do not overlap with the longer measurements of Lophostoma silvicolum and Trachops cirrhosus. Phyllostoma angusticeps has a forearm length within the ranges of $P$. discolor and T. cirrhosus, and within the upper extreme for Tonatia saurophila; the forearm of $P$. elongatus is considerably longer and that of $L$. silvicolum, shorter. Based on length of tibia, $P$. discolor is clearly excluded from consideration. On the basis of size alone, the holotype of $P$. angusticeps is a better fit with the dimensions of $T$. saurophila and T. cirrhosus.

Gervais (1856:47-49) included descriptions of P. elongatus, Lophostoma silvicolum, and most likely Tonatia saurophila (under the name Tylostoma bidens) in his report and provided partial illustrations of these three bats,

Table 3: Standard statistics of selected measurements, in millimeters, of the holotype of Phyllostoma angusticeps and specimens in the Division of Mammals, USNM, of Lophostoma silvicolum, Phyllostomus discolor, P. elongatus, Tonatia saurophila, and Trachops cirrhosus.

\begin{tabular}{|c|c|c|c|c|c|c|}
\hline Species & $\mathbf{n}$ & Total length & Wing span ${ }^{\mathrm{a}}$ & Ear & Forearm & Tibia \\
\hline L. silvicolum & 20 & $92.8(85-101)$ & $429.2(420-453)^{a}$ & $37.6(34-40)$ & $53.2(50.0-58.4)$ & $24.5(22.5-28.7)$ \\
\hline P. discolor & 22 & $95.4(86-105)$ & $427(416-435)^{b}$ & $22.8(20-27)$ & $61.3(57.3-66.5)$ & $20.1(19.4-23.7)$ \\
\hline P. elongatus & 20 & $101.8(90-110)$ & $472.7(455-488)^{\mathrm{b}}$ & $30.0(25-33)$ & $66.7(62.4-69.5)$ & $25.3(23.4-26.9)$ \\
\hline T. saurophila & 20 & $95.4(80-108)$ & $420.8(405-437)^{\mathrm{b}}$ & $0.5(22-35)$ & $56.1(49.8-60.1)$ & $25.7(22.6-27.9)$ \\
\hline T. cirrhosus & 20 & $99.6(90-110)$ & 390,404 & $36.0(33-40)$ & $60.9(57.9-63.2)$ & $25.3(24.2-28.7)$ \\
\hline P. angusticeps & 1 & 90 & 400 & - & 60 & 25 \\
\hline
\end{tabular}

Total length and ear measurements are from specimen labels. Forearm and tibia lengths measurements are from dry specimens; wingspan of first five species was measured in the field on fresh specimens. All measurements of $P$. angusticeps are from dry holotype.

${ }^{a} n$, Five; ${ }^{b} n$, three. 


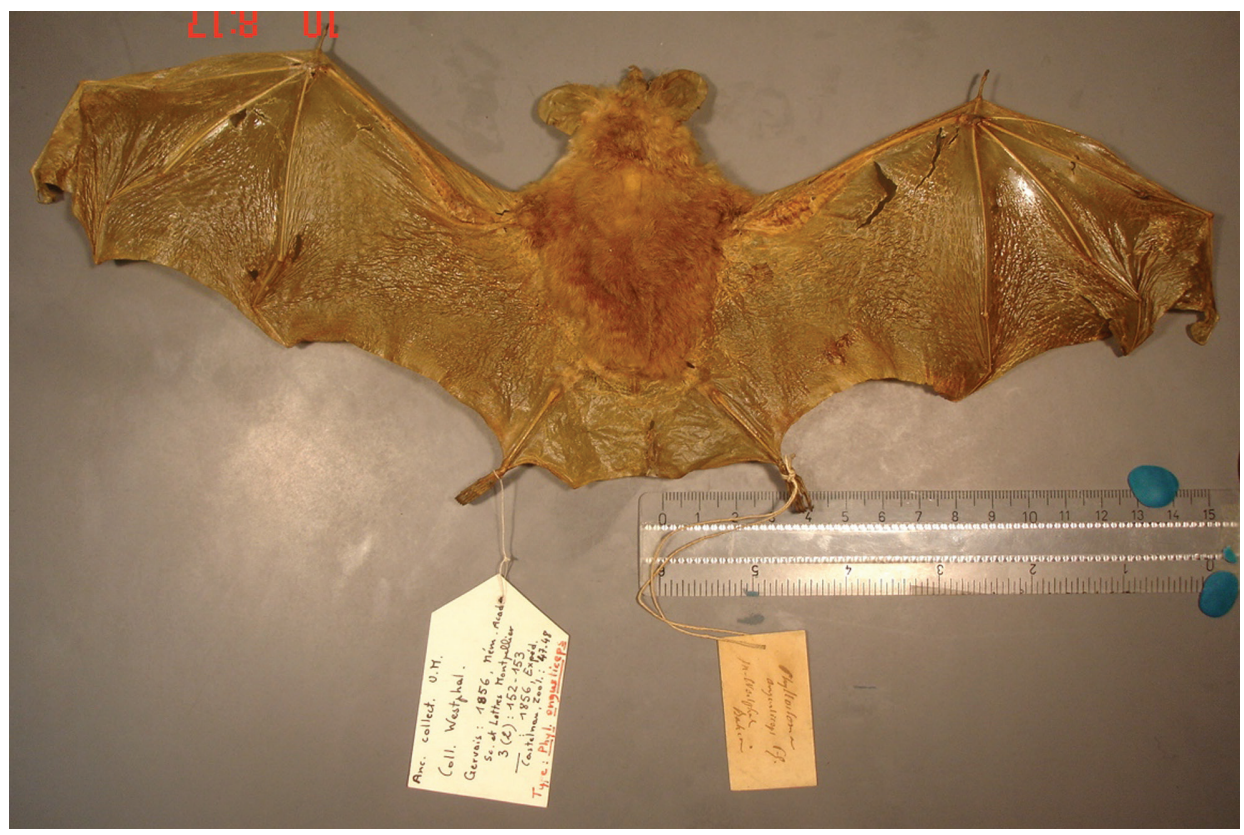

Figure 1: Dorsal view of the holotype of Phyllostoma angusticeps.

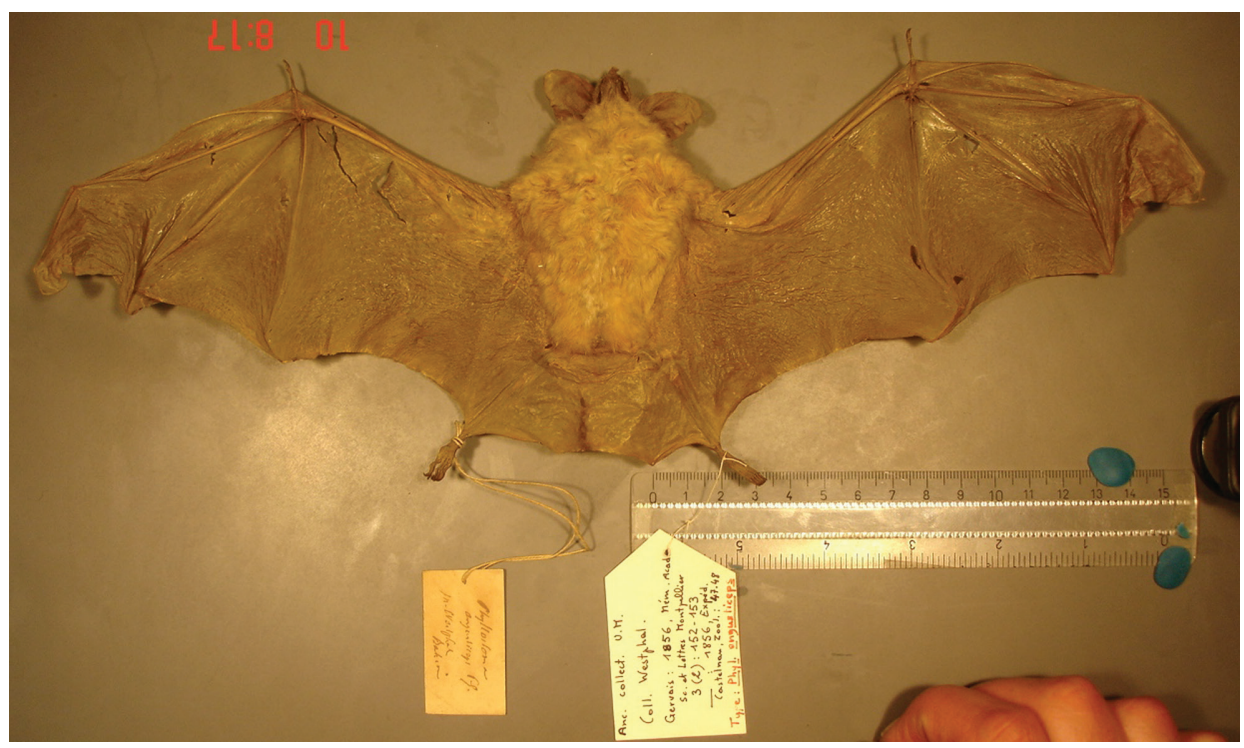

Figure 2: Ventral view of the holotype of Phyllostoma angusticeps.

including dentitions. Gervais (1856:48) also described the skull and dentition of Phyllostoma angusticeps, but provided no illustrations. It is possible that the skull still exists, but likely would not be associated with the skin because the skin was thought to represent a Phyllostoma discolor.

The skin covering the chin has short, stud-like papillae that appear identical to the sensory warts of Trachops cirrhosus as seen on dried skins. These diagnostic papillae are not found on any species of Phyllostomus, nor found in any other phyllostomatine. Therefore, based on size comparisons and skin morphology, we conclude that Phyllostoma angusticeps Gervais, 1856, is a junior synonym of Trachops cirrhosus (Spix 1823).

Additionally, as confirmed during previous and present studies, as well as the detailed review by Dobson (1878), several specimens from the Castelnau's collection are currently in The Natural History Museum, London. That mammal collection needs to be searched to see if additional Castelnau material can be located. 
Acknowledgments: We thank Harvard University for supporting J. A.-C's research through an Ernst Mayr Award. We also express appreciation to Mdm. Monique Vianey-Liaud for kindly providing working space, use of a microscope, and a specimen study permit to J. A.-C. Paula Jenkins and Daphne Hills, Mammal Group, Department of Zoology, The Natural History Museum (London), very kindly allowed the senior author and T. McCarthy to search through the Castelnau specimens. Barbara Herzig, of the Naturhistorisches Museum, Vienna, and Henry Turni of the Zoologisches Museum der Humboldt Universität zu Berlin, kindly searched their respective collections for specimens described by Gervais from the original Castelnau collections. We also acknowledge curators of the mammal collections of the Muséum d'histoire naturelle, Genève, and of the MNHN, who kindly allowed examination and measurement of specimens in their care. Robert Fisher commented on an early draft of this report. We also appreciate the comments of anonymous reviewers. Support for Gardner's research comes from the USGS Ecosystems Mission Area. Any use of trade, firm, or product names is for descriptive purposes only and does not imply endorsement by the US Government.

\section{References}

Carter, D.C. and P.G. Dolan. 1978. Catalogue of type specimens of Neotropical bats in selected European museums. Special Publications, The Museum Texas Tech University 15: 1-136.

Castelnau, F. de. 1850-1856. Expédition dans les parties centrales de l’Amérique du Sud, de Rio de Janeiro à Lima, et de Lima au
Para: exécuté par ordre du gouvernement Français pendant les années 1843 à 1847. P. Bertrand, Paris, 15 volumes (bound in 14). 8 vo, 4 to and folio.

Cramer, M.J., M.R. Willig and C. Jones. 2001. Trachops cirrhosus. Mamm. Species 656: 1-6.

Dobson, G.E. 1878. Catalogue of the Chiroptera in the collection of the British Museum. British Museum (Natural History), London, $x x x v i+1-567+30$ plates.

Garbino, G.S.T. and A. Tejedor. 2012. Natalus macrourus (Gervais, 1856) (Chiroptera: Natalidae) is a senior synonym of Natalus espiritosantensis (Ruschi, 1951). DOI 10.1515/mammalia-2012-0090, pp. 4. [Print copy: Mammalia 77(2):23-240, 2013.].

Gervais, M.P. 1856. Documents zoologiques pour servir à la Monographie des Chéiroptères Sud-Américains. pp. 25-87 + plates 7-14 (1855). In: (F. de Castelnau, ed.) Zoologie de l’Expédition dans les parties centrales de l'Ámerique du Sud. Chez P. Bertrand, Libraire-Éditeur, Paris.

Kwiecinski, G.G. 2006. Phyllostomus discolor. Mamm. Species 801: 1-11.

Medellín, R. A., and H. T. Arita. 1989. Tonatia evotis and Tonatia silvicola. Mamm. Species 334: 1-5.

Palmer, T.S. 1904. Index generum mammalium: a list of the genera and families of mammals. North American Fauna 23:1-984.

Papavero, N. 1971. Essays on the history of Neotropical dipterology, with special reference to collectors (1750-1905). Vol. I. Museu de Zoologia, Universidade de São Paulo vii + 446 pp.

Rode, P. 1941. Catalogue des types de mammifères du Muséum National d'Histoire Naturelle. II. Ordre des Chiroptères. Bulletin du Muséum National d'Histoire Naturelle 13: 227-252.

Simmons, N.B. 2005. Order Chiroptera. In: (D.E. Wilson and D.M. Reeder, eds.) Mammal species of the world: a taxonomic and geographic reference, third edition. The Johns Hopkins University Press, Baltimore. pp. 312-529.

Williams, S.L. and H.H. Genoways. 2008. Subfamily phyllostominae. In: (A.L. Gardner, ed.) Mammals of South America. Volume 1: Marsupials, xenarthrans, shrews, and bats. The University of Chicago Press, Chicago. pp. 255-300. 